\title{
RISIKO PERBANKAN DENGAN ALTMAN Z SCORE : KAJIAN PADA BANK YANG TERDAFTAR DI BURSA EFEK INDONESIA
}

\author{
Poppie Indriyanti \\ Institut Ilmu Sosial dan Manajemen STIAMI \\ popiemantu@bni.co.id
}

\begin{abstract}
Abstrak. Penelitian ini dilakukan untuk mengetahui risiko perbankan dengan Altman Z Score pada bank-bank konvensional yang terdaftar di Bursa Efek Indonesia. Data yang digunakan pada penelitian ini merupakan data sekunder yang diperoleh dari laporan keuangan tahunan bankbank konvensional selama periode 2003-2016 yang termuat dalam situs resmi Bursa Efek Indonesia.

Fokus penelitian (research focuses) pada topik yang telah diteliti adalah risiko perbankan berdasarkan Altman Z Score. Dari keempat penelitian yang ditelaah, persamaannya adalah semua penelitian menggunakan pendekatan penelitian kuantitatif. Hal tersebut berarti untuk menilai Altman Z-Score dalam mengamati risiko perbankan, pendekatan kuantitatif adalah pendekatan yang paling tepat.

Dari keempat penelitian tersebut, hasil penelitian menunjukkan risiko perbankan dengan Altman Z Score, dari tahun 2003-2016 bank-bank yang terdaftar di Bursa Efek Indonesia secara umum dalam kategori bangkrut. Namun, penelitian Ganesha dkk (2012) menunjukkan model nilai Z pada tahun 2003-2006 tidak bisa menunjukkan tingkat keakuratan yang cukup baik bila diukur per tiap tahun. Penelitian Irwansyah (2017) menunjukkan pada periode 2013-2016, hanya satu bank yakni Bank Jtrust Indonesia Tbk (kode bank BCIC) masuk dalam kategori sehat. Selain itu, Bank Mandiri (Persero) Tbk dengan kode bank BMRI, sudah mulai meningkat dari prediksi kategori bangkrut ke prediksi kategori grey area.
\end{abstract}

Kata Kunci: Risiko Perbankan, Altman Z-Score, Bank-bank Konvensional yang Terdaftar di BEI 2013-2016, studi kepustakaan/ literatur

Abstract. Abstract. This research was conducted to find out banking risk with Altman Z Score on conventional banks listed on Indonesia Stock Exchange. The data used in this study is secondary data obtained from the annual financial statements of conventional banks during the period 2003-2016 contained in the official website of the Indonesia Stock Exchange.

The focus of research (research focuses) on the topic that has been studied is the risk of banking based on Altman Z Score. Of the four studies examined, the equation is all research using quantitative research approach. It means to assess the Altman Z-Score in observing banking risk, the quantitative approach is the most appropriate approach.

Of the four studies, the results show banking risk with Altman Z Score, from 2003-2016 the banks listed on the Indonesia Stock Exchange are generally in the category of bankrupt. However, Ganesha et al (2012) study shows the Z value model in 2003-2006 can not show a good enough accuracy level when measured per year. Irwansyah's research (2017) shows that in the period 2013-2016, only one bank, namely Bank Jtrust Indonesia Tbk (BCIC bank code) entered into the healthy category. In addition, Bank Mandiri (Persero) Tbk with BMRI bank code, has started to increase from the predicted category of bankruptcy to the prediction of gray area category.

Keywords: Banking Risk, Altman Z-Score, Conventional Banks Listed on IDX 2013-2016, literature / literature study 


\section{PENDAHULUAN}

Perekonomian tumbuh dan berkembang dengan berbagai macam lembaga keuangan. Salah satu di antara lembaga-lembaga keuangan tersebut yang nampaknya paling besar peranannya dalam perekonomian adalah lembaga keuangan bank, yang lazimnya disebut bank. Bank merupakan lembaga keuangan yang menjadi tempat bagi perusahaan, badan - badan pemerintah dan swasta, maupun perorangan menyimpan danadananya. Melalui kegiatan perkreditan dan berbagai jasa yang diberikan, bank melayani kebutuhan pembiayaan serta melancarkan mekanisme sistem pembayaran bagi semua sektor perekonomian.

Perbankan memegang peranan penting dalam kehidupan masyarakat. Perbankan merupakan perusahaan yang dalam kegiatannya berhubungan langsung dengan masyarakat. Kegiatan perbankan begitu dipengaruhi oleh kepercayaan nasabah atau masyarakat luas. Apabila dalam tubuh bank terjadi gejolak maka akan muncul reaksi keras dari masyarakat.

Dalam Krisis ekonomi yang diawali dengan dilikuidasinya 16 bank pada bulan November 1997, telah menyebabkan bangsa Indonesia terjerumus dalam tingkat kemiskinan yang meningkat secara drastis yaitu mencapai 49,5 juta orang.

Tahun 1999 walau tingkat kemiskinan mengalami penurunan namun tingkat keparahannya lebih besar dibanding tahun sebelumnya. Kemiskinan di Indonesia terlihat dari meningkatnya jumlah pengangguran, meningkatnya anak usia sekolah yang putus sekolah dan turunnya kualitas kesehatan masyarakat (Ade Arthesa dan Edia Handiman, 2006:57).

Industri perbankan di Indonesia khususnya, amat rentan terhadap isu-isu atau kejadian politik, ekonomi maupun sosial. Sebagai contoh, bila ada kasus pada entitas dalam industri tersebut, misal isu pada satu bank, maka akan mempengaruhi kepercayaan pada industri perbankan.

Otoritas Jasa Keuangan (OJK) menyebut ada empat faktor penting yang akan mewarnai perkembangan dan pertumbuhan industri perbankan di masa depan. Melalui penjelasan resmi dalam booklet perbankan 2014 yang diluncurkan OJK, Muliaman Hadad, Ketua Dewan Komisioner OJK, memaparkan strategi dan bisnis model industri perbankan akan dipengaruhi empat faktor. Pertama, seiring peningkatan jumlah penduduk usia produktif dan kelas menengah, konsumen perbankan menuntut layanan lebih cepat dan fleksibel dengan produk yang lebih variatif. Instrumen kredit juga semakin terhubung dengan instrumen pasar uang dan pasar modal, sehingga OJK melihat kemungkinan mengintegrasikan produk perbankan dengan instrumen pasar uang dan pasar modal. Kedua, perbankan akan meningkatkan penyaluran kredit investasi terutama sektor manufaktur, energi, dan infrastruktur, dalam rangka memperbarui dan merevitalisasi kapasitas perindustrian, sehingga dapat menghasilkan produk-produk dengan nilai tambah tinggi. OJK akan melakukan evaluasi secara hati-hati dalam proses pemberian kredit. Ketiga, perubahan lanskap industri perbankan yang menuntut reformasi yang khomprehensif, mencakup struktur permodalan, likuiditas, governance, dan sekuritisasi, guna menurunkan kemungkinan kegagalan institusi. Di tengah keterbatasan modal domestik dan pembatasan keterlibatan modal asing, peningkatan permodalan perbankan menjadi tidak mudah. Keempat, walaupun integrasi di sektor perbankan dalam Masyarakat Ekonomi ASEAN (MEA) baru terwujud di 2020, namun terintegrasinya pasar modal 2015 dapat memberikan tekanan pendanaan dan pembiayaan bank. Sebab nasabah memiliki alternatif lebih banyak dalam hal penempatan dana. Selain itu, dunia usaha tanah air lebih mudah masuk bursa luar negeri sehingga berpotensi mengurangi pangsa kredit domestik.

(http://keuangan.kontan.co.id/news/inilah-4faktor-yang-akan-mempengaruhi-bisnis-bank, 2014).

Daya saing perusahaan juga sangat ditetukan oleh kinerja perusahaan itu sendiri. Salah satu aspek penting mengenai kinerja perusahaan adalah aspek keuangan. Kinerja keuangan yang buruk akan menghambat 
kinerja perusahaan dalam meningkatkan hasil produksi. Jika tidak segera diatasi maka perusahaan tersebut akan ternancam bangkrut. Kebangkrutan suatu usaha dapat dilihat dan diukur melalui keuangan perusahaan dengan cara menganalisis laporan keuangan. Analisis laporan keuangan merupakan suatu cara untuk mengartikan angka - angka yang terdapat pada laporan keuangan. Dalam melakukan analisis laporan keuangan berbagai alat dan teknik dapat digunakan. Alat yang paling umum digunakan adalah analisis rasio keuangan.

Perusahaan yang ingin tetap berkembang dituntut adanya manajemen yang berkualitas untuk mengelola perusahaan dan melihat peluang yang ada sehingga dapat mempertahankan kelangsungan hidup perusahaan dari kebangkrutan. Dengan penggunaan laporan keuangan dalam menganalisis kondisi keuangan perusahaan secara menyeluruh dapat menjadi media informasi yang digunakan para investor untuk menanamkan dananya pada perusahaan.

Saat ini perusahaan yang go public memanfaatkan keberadaan pasar modal sebagai sarana untuk mendapatkan sumber dana atau alternatif pembiayaan. Adanya pasar modal dapat dijadikan sebagai alat untuk merefleksikan kinerja dan kondisi keuangan perusahaan. Pasar akan merespon positif melalui peningkatan harga saham perusahaan jika kondisi keuangan dan kinerja perusahaan bagus. Para investor dan kreditur sebelum menanamkandananya pada suatu perusahaan akan selalu melihat terlebih dahulu kondisi keuangan perusahaan tersebut. Oleh karena itu, analisis dan prediksi atas kondisi keuangan suatu perusahaan adalah sangat penting. (Atmini, 2005) dalam (Syamsul Hadi dan Atika Anggraeni, 2010).

Menurut Edward I. Altmarn, dalam penelitiannya tersebut setelah menyeleksi 22 rasio keuangan, altman menentukan lima rasio keuangan yang dapat digunakan untuk mendeteksi kebangkrutan perusahaan beberapa saat sebelum perusahaan tersebut bangkrut. Kelima rasio tersebut terdiri dari : modal kerja terhadap aktiva, laba ditahan terhadap total aktiva, laba sebelum bunga dan pajak terhadap aktiva, nilai pasar modal saham terhadap nilai buku hutang, dan penjualan terhadap aktiva. Analisis tersebut dikenal dengan analisis Z-
Score yang dapat memprediksi secara akurat tentang kinerja perusahaan, serta kemungkinan kondisi kesehatan keuangan di masa yang akan datang, apakah perusahaan mengalami kebangkrutan, rawan bangkrut, atau dalam keadaan sehat. Hal tersebut sangat membantu bagi para investor dalam menanamkan modalnya, apakah ia akan menjual, membeli, atau bahkan menahan investasinya pada perusahaan yang bersangkutan. Dan bagi para leaders (pemimpin) perusahaan, mereka mempunyai kepentingan untuk dapat menyusun, mempertimbangkan, dan memperbaiki serta menentukan keputusan yang tepat agar dapat dipertanggung jawabkan kepada para pemegang saham atau investor.

Berdasarkan laporan keuangan akan dapat dihitung sejumlah rasio keuangan yang lazim dijadikan dasar prediksi kebangkrutan. Hasil analisis laporan keuangan akan membantu mengintepretasikan berbagai hubungan serta kecenderungan yang dapat memberikan dasar pertimbangan mengenai prediksi masa depan bank apakah dapat bertahan atau tidak (S.Munawir, 2002: 292). Dari uraian sebelumnya, tujuan penelitian ini adalah menganalisis risiko perbankan berdasarkan Altman Z Score pada perusahaan yang terdaftar di Bursa Efek Indonesia.

\section{TINJAUAN LITERATUR}

Bank adalah suatu badan usaha yang tugas utamanya sebagai lembaga perantara keuangan (financial intermediaries), yang menyalurkan dana dari pihak yang berkelebihan dana atau kekurangan dana (deficit unit) pada waktu yang ditentukan. Bank adalah suatu badan yang bertujuan untuk memuaskan kebutuhan kredit, baik dengan alat-alat pembayarannya sendiri atau dengan uang yang di-perolehnya dari orang lain, maupun dengan jalan memperedarkan alat-alat penukar baru berupa uang giral (G.M. Verryn Stuart). Bank adalah badan yang usaha utamanya menciptakan kredit (Suyatno, 1996). Bank adalah suatu jenis lembaga keuangan yang melaksanakan berbagai macam jasa, seperti memberikan pinjaman, mengedarkan mata uang, pengawasan terhadap mata uang, bertindak sebagai tempat penyimpanan bendabenda berharga, membiayai perusahaanperusahaan, dan lain-lain (A. Abdurrachman, 
Ensiklopedia Ekonomi Keuangan dan Perdagangan).

Terdapat beberapa alat analisis yang dapat digunakan untuk memprediksi tingkat kesehatan dan kebangkrutan perusahaan. Salah satu alat analisis yang digunakan saat ini adalah analisis model nilai Z Altman. Studi yang mengukur keefektifan model nilai $\mathrm{Z}$ Altman menunjukkan bahwa model ini memiliki tingkat keakuratan yang cukup tinggi dalam memprediksi kebangkrutan perusahaanperusahaan di Amerika Serikat untuk 2 tahun masa observasi sebelum kebangkrutan, yaitu dengan tingkat akurasi 95\% untuk 1 tahun masa observasi dan $72 \%$ untuk 2 tahun masa observasi (Altman, 2000). Akan tetapi, model nilai $\mathrm{Z}$ Altman adalah sebuah model analisis untuk menilai kinerja sebuah perusahaan manufaktur. Untuk menganalisis kinerja dan tingkat kesehatan perbankan, Bank Indonesia telah memiliki suatu metode yang disebut dengan CAMELS. Komponen CAMELS terdiri dari Capital, Assets Quality, Management, Earnings, Liquidity, Sensitivity, diadopsi dari AS yaitu CAMEL. Rasio-rasio yang digunakan di dalam CAMELS akan digunakan sebagai variabel-variabel penentu untuk membuat model prediksi analogi dengan metode Altman.

Penelitian dalam bidang ini di Indonesia telah dilakukan oleh Paul Barnes (1987), Ou dan Penman (1989), Davis (1994), Machoedz (1994), Payamta (1999), Lisetyati (2000), dan Sumarta (2000). Dalam penelitian Lisetyati (2000) data yang digunakan diambil dari sektor perbankan, yaitu dari Direktori Perbankan Indonesia untuk periode 19951999, terpilih sebanyak 141 bank, terhadap 11 rasio keuangan yang dikategorikan menjadi capital asset quality, management competence, earning power, dan liquidity. Tahun 2002 menjadi awal permulaan penelitian karena Indonesia pada tahun 2001-2005 adalah tahuntahun krisis yang terjadi pada perbankan Indonesia setelah tahun 1997, tidak dipilihnya tahun 2001 agar data yang diambil tidak terlampau jauh dari tahun sekarang 2008. Tidak didapatkannya data tahun 2007-2008 karena pada tahun 2008 neraca laporan keuangan BI belum dikeluarkan sebelum akhir tahun. Sedangkan tahun 2007, banyak data neraca laporan keuangan yang masih sangat sulit untuk didapatkan karena berbagai macam kebijakan BI dan kebijakan dari masingmasing BUSN sendiri. Penelitian ini meneliti pengaruh CAMEL tiap-tiap tahun terhadap kinerja perbankan tahun berikutnya. Jenis perbankan menurut UU perbankan berdasarkan kepemilikannya terbagi menjadi BUMN, BUMD, BUSN, Bank Campuran, dan Bank Asing. Selama periode 2002-2006, jumlah BUSN yang bermasalah - bahkan dilikuidasi, terbanyak daripada jenis bank lainnya. Hal ini membuat objek penelitian akan difokuskan pada jenis BUSN.

Terdapat tiga istilah umum yang biasa terdapat dalam literatur mengenai definisi kesulitan keuangan perusahaan, yaitu kegagalan bisnis, ketidakmampuan melunasi utang, dan kebangkrutan (Altman, 1983 dalam Kusumastuti, 2001). Meskipun istilah-istilah tersebut terkadang digunakan secara bergantian, sebenarnya mereka memiliki arti yang berbeda. Kegagalan bisnis (failure), berarti rate of return terhadap modal yang diinvestasikan lebih rendah secara signifikan dan terjadi terus menerus daripada rate of return yang berlaku pada investasi lain yang serupa. Beberapa kriteria ekonomi yang berbeda juga telah digunakan, di antaranya pendapatan yang tidak cukup untuk menutup biaya serta rate of return rata- rata terhadap investasi yang berada di bawah biaya modal perusahaan. Namun, keputusan normatif untuk tidak melanjutkan operasi biasanya didasarkan pada rate of return yang diharapkan dan kemampuan perusahaan untuk menutupi biaya variabelnya.

Ketidakmampuan melunasi utang (insolvency), secara teknis, merupakan sebuah istilah yang menggambarkan kinerja negatif sebuah perusahaan, timbul ketika sebuah perusahaan tidak dapat memenuhi current liabilities yang dimilikinya, yang merupakan sinyal dari rendahnya tingkat likuiditas perusahaan tersebut. Walter (1957) dalam Kusumastuti (2001) membahas tentang ukuran ketidakmampuan melunasi utang secara teknis dalam lingkup ekuitas. Kriteria utama untuk mendeskripsikan hal ini adalah arus kas bersih 
relatif terhadap kewajiban sekarang. Walaupun umumnya berlangsung sementara, namun hal ini dapat menyebabkan pernyataan kebangkrutan formal, sehingga diperlukan penilaian tingkat kesehatan bank yang menyeluruh. Penilaian tingkat kesehatan bank secara kuantitatif dilakukan terhadap 5 faktor, yaitu faktor Permodalan (Capital), Kualitas Aktiva Produktif (Asset), Manajemen, Rentabilitas (Earning) dan Likuiditas. Analisis ini dikenal dengan istilah Analisis CAMEL.

\section{Analisis Z-Score}

Analisis Z-Score adalah suatu
alat/metode yang digunakan untuk
memprediksi kondisi perusahaan apakah
dalam keadaan sehat, atau tidak dan juga
menunjukkan kinerja perusahaan yang
sekaligus merefleksikan prospek perusahaan di
masa yang akan datang. Altman menggunakan
5 rasio keuangan untuk memprediksi
kebangkrutan suatu perusahaan. Metode ini
diformulasikan sebaga berikut:
$\mathrm{Zi}=1 ., 2 \mathrm{X} 1+1,4 \mathrm{X} 2+3,3 \mathrm{X} 3+0,6 \mathrm{X} 4+\mathrm{X} 5$ dengan:
$\mathrm{X} 1=($ Aktiva lancar-Utang Lancar $) /$ Total Aktiva
X2 = Laba yang ditahan / Total Aktiva
X3 = Laba sebelum bunga dan pajak / Total Aktiva
X4 = Nilai pasar modal / Nilai buku hutang $\mathrm{X} 5=$ Penjualan $/$ Total aktiva

\section{Rasio-Rasio Z-Score}

Rasio-rasio dalam Z-Score ini masingmasing memberikan gambaran tersendiri mengenai perusahaan, yaitu:

\section{Working Capital to Total Asset (Rasio} Modal Kerja terhadap Total Aktiva)

Rasio pertama yang digunakan sebagai alat untuk memprediksi kebangkrutan adalah rasio modal kerja terhadap total aktiva. Rasio ini digunakan untuk mengukur likuiditas. Aktiva likuid bersih atau modal kerja bersih adalah selisih antara total aktiva lancar dikurangi total kewajiban lancar. Umumnya, bila perusahaan mengalami kesulitan keuangan, modal kerja akan turun lebih cepat daripada total aktiva menyebabkan rasio ini turun. Modal kerja bersih yang negative juga kemungkinan besar akan menghadapi masalah dalam menutupi kewajiban jangka pendeknya karena tidak tersedianya aktiva lancar yang cukup untuk menutupi kewajiban tesebut. Sebaliknya, perusahaan dengan modal kerja yang bernilai positif jarang sekali menghadapi kesulitan dalam melunasi kewajibannya. Rasio modal kerja menunjukkan jumlah modal kerja yang dimiliki pada setiap $\mathrm{Rp} 1,00$ aktiva perusahaan.

Retained Earning to Total Assets (Rasio Laba Ditahan terhadap Total Aktiva)

Retained Earning / Total Assets (X2) merupakan rasio profitabilitas yang menilai kemampuan perusahaan dalam menghasilkan laba selama masa operasi perusahaan. Umur perusahaan berpengaruh terhadap rasio tersebut karena semakin lama perusahaan beroperasi, memungkinkan untuk memperlancar akumulasi laba ditahan. Hal tersebut menyebabkan perusahaan yang masih relatif muda pada umumnya akan menunjukkan hasil rasio yang rendah, kecuali yang labanya sangat besar pada masa awal berdirinya. Semakin besar rasio ini, menunjukkan semakin besarnya peranan laba ditahan dalam membentuk dana perusahaan. Semakin kecil rasio ini menunjukkan kondisi keuangan perusahaan yang tidak sehat. Rasio laba ditahan terhadap total aktiva menunjukkan bahwa setiap Rp 1,00 aktiva perusahaan dijamin oleh saldo laba ditahan.

\section{Earning Before Interest and Taxes to} TotalAssets (Rasio EBIT terhadap Total Aktiva)

Rasio ini megukur kemampulabaan, yaitu tingkat pengembalian aktiva, yang dihitung dengan membagi laba sebelum bunga dan pajak (EBIT) tahunan perusahaan dengan total aktiva pada neraca akhir tahun. Rasio ini juga dapat digunakan sebagai ukuran sebarapa besar produktivitas penggunaan dana yang dipinjam. Rasio EBIT terhadap total aktiva menunjukkan laba bersih sebelum bunga dan pajak yang dapat dihasilkan dari setiap $\mathrm{Rp}$ 1,00 aktiva perusahaan.

Market Value Of Equity to Book Value Of Liabilities (Rasio Nilai Pasar Modal terhadap Total Hutang) 
Rasio ini menunjukkan kemampuan perusahaan untuk memenuhi kewajibankewajiban jangka panjang dari nilai modal sendiri (saham biasa). Nilai pasar modal sendiri diperoleh dengan mengalikan jumlah lembar saham biasa yang beredar denganharga pasar per lembar saham biasa. Nilai buku hutang diperoleh dengan menjumlahkan kewajiban lancar dengan kewajiban jangka panjang. Semakin kecil rasio ini, menunjukkan kondisi keuangan peusahaan yang tidak sehat. Rasio nilai pasar modal sendiri terhadap nilai buku total kewajiban menunjukkan setiap Rp 1,00 dari total kewajiban digunakan untuk membiayai modal saham.

\section{Sales to Total Assets (Rasio Penjualan} terhadap Total Aktiva)

Rasio ini merupakan rasio aktivitas yang digunakan untuk mengukur kemampuan perusahaan dalam dalam meningkatkan volume penjualan. Rasio ini mencerminkan efisiensi manajemen dalam menggunakan keseluruhan aktiva perusahaan untuk menghasilkan penjualan dan mendapatkan laba. Semakin rendah rasio ini menunjukkan semakin rendah tingkat pendapatan perusahaan, sehingga menunjukkan kondisi keuangan perusahaan yang tidak sehat. Rasio penjualan terhadap total aktiva menunjukkan efektifitas penggunaan seluruh aktiva perusahaan dalam rangka menghasilkan penjualan bersih yang dapat dihasilkan oleh setiap $\mathrm{Rp} 1,00$ yang diinvestasikan dalam bentuk aktiva perusahaan.

\section{Kriteria Altman Z-Score}

Kriteria yang digunakan untuk memprediksi kebangkrutan perusahaan dengan model ini adalah, perusahaan yang mempunyai skor $\mathrm{Z}>2,90$ diklasifikasikan sebagai perusahaan sehat, sedangkan perusahaan yang mempunyai skor $\mathrm{Z}<1,20$ diklasifikasikan

sebagai perusahaan potensial bangkrut. Selanjutnya skor antara 1,20 sampai 2,90 diklasifikasikan sebagai perusahaan pada daerah rawan bangkrut (Hanafi dan Halim, 2005).

\section{METODE PENELITIAN}

Penelitian ini adalah penelitian kepustakaan. Secara keseluruhan peneliti menganalisis hasil penelusuran dari 4 hasil penelitian dengan pertanyaan utama (Research Questions) dalam penelitian ini meliputi:

1. Bagaimana fokus penelitian (research focuses) pada topik yang telah diteliti?

2. Metodologi dan jenis paper (paper type) apa yang digunakan?

Hasil penelitian ini memberikan pendekatan penelitian yang komprehensif tentang risiko perbankan berdasarkan Altman Z Score pada industri perbankan yang terdaftar di BEI, serta implikasi dan pedoman bagi akademisi dan praktisi lainnya.

\section{PEMBAHASAN}

Penelitian yang dilakukan Irwansyah (2017) bertujuan membuktikan keakuratan prediksi kebangkrutan model Altman Z-Score pada bank-bank konvensional yang terdaftar di Bursa Efek Indonesia. Data yang digunakan pada penelitian ini merupakan data sekunder yang diperoleh dari laporan keuangan tahunan bank-bank konvensional selama periode 20132016 yang termuat dalam situs resmi Bursa Efek Indonesia. Teknik analisis data yang digunakan adalah model prediksi kebangkrutan Altman Z-Score, dengan menggunakan lima variabel yang mewakili rasio likuiditas $X_{1}$, rasio profitabilitas $X_{2}$ dan $\mathrm{X}_{3}$, dan rasio aktivitas $\mathrm{X}_{4}$ dan $\mathrm{X}_{5}$. Rumus $Z$ score $=1 ., 2 \mathrm{X} 1+1,4 \mathrm{X} 2+3,3 \mathrm{X} 3+0,6 \mathrm{X} 4+$ $X 5$. Bila kriteria Z-Score adalah $Z>2,90$ dikategorikan sebagai perusahaan sehat. ZScore antara 1,23 sampai 2,90 dikategorikan sebagai perusahaan pada grey area atau daerah kelabu. Sedangkan Z-Score Z $<1,23$ dikategorikan sebagai perusahaan potensial bangkrut. Dari hasil penelitian, analisis ZScore yang telah dilakukan pada periode 20132016 dapat diketahui bahwa bank-bank konvensional merupakan perusahaan yang mayoritas berada dalam prediksi bangkrut. Nilai terendah dari Z-Score adalah 1,23. Hanya satu bank Bank Jtrust Indonesia Tbk (kode bank BCIC) masuk dalam kategori sehat. Selain itu, Bank Mandiri (Persero) Tbk dengan kode bank BMRI, sudah mulai 
meningkat dari prediksi kategori bangkrut ke prediksi kategori grey area.

Ganesha dkk (2012) Terdapat dua tujuan utama yang ingin dicapai oleh penelitian ini, yaitu: untuk mengetahui tingkat akurasi model analisis prediksi kesehatan bank umum swasta nasional dengan menggunakan rasio CAMEL, dan membuat model nilai $\mathrm{Z}$ bagi bank umum swasta nasional dengan menggunakan multiple discriminant analysis (MDA) seperti halnya pada model nilai Z Altman. Penentuan model nilai $\mathrm{Z}$ menggunakan rasio-rasio kesehatan perbankan tentang Capital, Assets, Earnings dan Liability (CAEL), kemudian membuat model nilai $\mathrm{Z}$ baru khusus untuk bank umum swasta nasional di Indonesia dengan menggunakan analisis statistik MDA, dengan bantuan program SPSS. Sampel yang digunakan adalah 30 buah bank, terdiri atas 19 bank dalam kategori sehat pada tahun 2002 dan 11 bank dalam kategori bermasalah pada tahun yang sama. Hasil penelitian menunjukkan bahwa model nilai $\mathrm{Z}$ pada tahun 2003-2006 tidak bisa menunjukkan tingkat keakuratan yang cukup baik bila diukur per tiap tahun. Sebaliknya, model nilai $\mathrm{Z}$ baru yang dihasilkan oleh penelitian ini memiliki tingkat akurasi yang cukup baik dalam memprediksi kasus tingkat kebangkrutan bank umum swasta nasional di Indonesia, dengan tingkat akurasi sebesar 86,7\% pada tahun 2002 dan dengan rata-rata akurasi $71,67 \%$ untuk 4 tahun masa tinjauan.

Penelitian Kamal (2012) adalah untuk menguji prediksi kebangkrutan pada perusahaan perbankan yang terdaftar di Bursa Efek Indonesia. Karena perbankan mengambil peranan penting dalam perekonomian Indonesia. Dengan menggunakan metode Altman Z-score untuk melihat seberapa besar prediksi kebangkrutan periode 2008-2010 di perusahaan perbankan. Menghitung masingmasing prediksi kebangkrutan pada setiap bank yang berjumlah 20 bank. Data yang digunakan dalam penelitian ini adalah laporan keuangan tahunan bank yang berada pada Bursa Efek Indonesia. Teknik analisis yang digunakan adalah model prediksi kebangkrutan Altman Z-score. Dengan menggunakan lima variabel yang mewakili rasio likuiditas $\mathrm{X}_{1}$, profitabilitas $\mathrm{X}_{2}$ dan $\mathrm{X}_{3}$, aktivitas $\mathrm{X}_{4}$ dan $\mathrm{X}_{5}$. Memiliki rumus Z-Score $=1,2 X_{1}+1,4 X_{2}+3,3 X_{3}+0,6 X_{4}+1,0 X_{5}$. Dengan kriteria penilaian Z-Score > 2,99 dikategorikan sebagai perusahaan yang sangat sehat. 1,81 < Z-Score $<2,99$ berada di grey area sehingga kemungkinan terselamatkan dan kemungkinan bangkrut sama besarnya tergantung dari keputusan kebijaksanaan manajemen perusahaan sebagai pengambil keputusan. Z-Score < 1,81 dikategorikan sebagai perusahaan yang memiliki kesulitan keuangan yang sangat besar dan beresiko tinggi sehingga kemungkian bangkrutnya sangat besar. Selama Periode pengamatan menunjukkan bahwa data penelitian sebanyak 20 bank go public masih ada beberapa yang berada dalam keadaan bangkrut. Tahun 2008, 95\% bank mengalami prediksi kebangkrutan dengan nilai di bawah 1,88 dan $5 \%$ berada pada grey area. Tahun 2009, ada beberapa bank yang mengalami perbaikan kondisi keuangan dengan adanya $40 \%$ bank berada dalam kondisi sehat, $45 \%$ bangkrut dan $15 \%$ berada pada grey area. Tahun 2010, mengalami peningkatan untuk kondisi sehat yaitu sebesar 55\%, 5\% grey area dan sisanya berada dalam kondisi bangkrut.

Fakhrurozi pada tahun 2007 melakukan penelitian, yang bertujuan menganalisis prediksi kebangkrutan perusahaan perbankan dan untuk menganalisis apakah ada pengaruh antara kebangkrutan bank terhadap harga saham pada perusahaan perbankkan di Bursa Efek JakartEI). Penelitian ini adalah termasuk penelitian populasi, yaitu ingin melihat dan meneliti semua populasi. Sedangkan populasi sasaran dalam penelitian ini adalah perusahaan perbankan di Bursa Efek Jakarta yang berjumlah 22 perusahaan. Data yang digunakan adalah laporan keuangan 22 perusahaan dan harga saham yang mendekati tanggal publikasi laporan keuangan. Variabel terikat (Y) dalam penelitian ini adalah harga saham. Sedangkan variabel bebas $(\mathrm{X})$ dalam penelitian ini adalah nilai Z-Score. Metode pengumpulan data yang digunakan adalah metode dokumentasi. Metode analisis datanya adalah analisis rasio Altman Z-Score dan analisis statistik. Pengolahan data menggunakan program SPSS (Statistical Product and Service Solution) for windows 
versi 13.00. Hasil penelitian ini menunjukan bahwa analisis rasio Altman Z-Score, pada tahun 2003 sampai tahun 2005 diperoleh nilai Z-Score yang masih rendah di bawah nilai 1,20 sehingga seluruh bank masuk dalam kategori bangkrut. Hanya satu bank yang pada tahun 2004 yang nilainya Altman Z-Score sebesar 1,83 itupun masih dalam kategori grey area. Sedangkan analisis regresi sederhana dengan SPSS versi 13.00, diperoleh model untuk memprediksi harga saham adalah persamaan $\mathrm{Y}=0,024+0,208 \mathrm{X}$, Thitung= 4,182 , koefisien determinasi R Square $(\mathrm{R} 2)=$ 0,215 . Berdasarkan hasil analisis Altman ZScore dapat disimpulkan dari tahun 2003 sampai 2005 seluruh perusahaan perbankan masuk dalam kategori bangkrut. Dari analisis regresi sederhana, dapat disimpulkan bahwa nilai Z-Score Altman berpengaruh terhadap harga saham sebesar 21,50\% sedangkan $78,50 \%$ dipengaruhi faktor lain. Bagi peneliti lain dapat dijadikan bahan referensi dan dapat dikembangkan dengan pelbagai disiplin ilmu pada kajian tentang prediksi kebangkrutan bank, sehinggga dapat ditemukan faktor lain yang dapat mempengaruhi harga saham pada perusahaan perbankan di Bursa Efek Jakarta (sekarang Bursa Efek Indonesia).

Berikut tabel 1 menunjukkan hasil penelitian yang ditelaah dalam penelitian ini Dari keempat penelitian tersebut persamaannya adalah semua penelitian menggunakan pendekatan penelitian kuantitatif. Hal tersebut berarti untuk menilai Altman Z-Score dalam mengamati risiko perbankan, pendekatan kuantitatif adalah pendekatan yang paling tepat.

Tabel 1

Hasil Penelitian

\begin{tabular}{|c|c|c|c|c|c|c|}
\hline No. & Referensi & Tahun & $\begin{array}{c}\text { Fokus } \\
\text { Penelitian }\end{array}$ & $\begin{array}{c}\text { Metode } \\
\text { Penelitian }\end{array}$ & Sumber & Negara \\
\hline 1 & Irwansyah & 2017 & $\begin{array}{c}\text { Bank, Altman Z } \\
\text { Score, Prediksi } \\
\text { Kebangkrutan }\end{array}$ & Kuantitatif & $\begin{array}{c}\text { Jurnal } \\
\text { Manajemen } \\
\text { STIE } \\
\text { Binaniaga }\end{array}$ & Indonesia \\
\hline 2 & $\begin{array}{l}\text { Agha Swara } \\
\text { Ganesha, } \\
\text { Tomy G. } \\
\text { Soemapradja, } \\
\text { Darman, } \\
\text { Desmizar }\end{array}$ & 2012 & $\begin{array}{l}\text { Model prediksi } \\
\text { kebangkrutan, } \\
\text { Altman, } \\
\text { CAMEL, } \\
\text { Multiple } \\
\text { Discriminant } \\
\text { Analysis }\end{array}$ & Kuantitatif & $\begin{array}{l}\text { BINUS } \\
\text { Business } \\
\text { Review }\end{array}$ & Indonesia \\
\hline 3 & $\begin{array}{c}\text { Siti Ibrah } \\
\text { Mustafa Kamal }\end{array}$ & 2012 & $\begin{array}{c}\text { Bank, Altman Z } \\
\text { Score, Prediksi } \\
\text { Kebangkrutan }\end{array}$ & Kuantitatif & $\begin{array}{c}\text { Jurusan } \\
\text { Manajemen } \\
\text { Fakultas } \\
\text { Ekonomi dan } \\
\text { Bisnis } \\
\text { Universitas } \\
\text { Hasanuddin }\end{array}$ & Indonesia \\
\hline 4 & Fakhrurozie & 2007 & $\begin{array}{c}\text { Bank, Altman Z } \\
\text { Score, Prediksi } \\
\text { Kebangkrutan }\end{array}$ & Kuantitatif & $\begin{array}{c}\text { Universitas } \\
\text { Negeri } \\
\text { Semarang } \\
\end{array}$ & Indonesia \\
\hline
\end{tabular}

Sumber: hasil penelitian terdahulu diolah peneliti, 2017

Pada fokus penelitian tentang risiko perbankan dengan Altman Z Score, penelitian Irwansyah (2017) menghasilkan analisis pada periode 2013-2016 yakni,_ bank-bank konvensional merupakan perusahaan yang mayoritas berada dalam prediksi bangkrut. Nilai terendah dari Z-Score adalah 1,23. Hanya satu bank Bank Jtrust Indonesia Tbk (kode bank BCIC) masuk dalam kategori sehat. Selain itu, Bank Mandiri (Persero) Tbk 
dengan kode bank BMRI, sudah mulai meningkat dari prediksi kategori bangkrut ke prediksi kategori grey area. Hasil penelitian sebelumnya dari Kamal (2012) selama periode pengamatan menunjukkan bahwa data penelitian sebanyak 20 bank go public masih ada beberapa yang berada dalam keadaan bangkrut. Tahun 2008, 95\% bank mengalami prediksi kebangkrutan dengan nilai di bawah 1,88 dan $5 \%$ berada pada grey area. Tahun 2009, ada beberapa bank yang mengalami perbaikan kondisi keuangan dengan adanya $40 \%$ bank berada dalam kondisi sehat, $45 \%$ bangkrut dan $15 \%$ berada pada grey area. Tahun 2010, mengalami peningkatan untuk kondisi sehat yaitu sebesar 55\%, 5\% grey area dan sisanya berada dalam kondisi bangkrut. Hasil penelitian Ganesha dkk (2012) menunjukkan model nilai $\mathrm{Z}$ pada tahun 20032006 tidak bisa menunjukkan tingkat keakuratan yang cukup baik bila diukur per tiap tahun. Sebaliknya, model nilai $\mathrm{Z}$ baru yang dihasilkan oleh penelitian ini memiliki tingkat akurasi yang cukup baik dalam memprediksi kasus tingkat kebangkrutan bank umum swasta nasional di Indonesia, dengan tingkat akurasi sebesar $86,7 \%$ pada tahun 2002 dan dengan rata-rata akurasi $71,67 \%$ untuk 4 tahun masa tinjauan. Sedangkan penelitian Fakhrurozi (2007) menunjukkan berdasarkan hasil analisis Altman Z-Score dapat disimpulkan dari tahun 2003 sampai 2005 seluruh perusahaan perbankan masuk dalam kategori bangkrut. Dari analisis regresi sederhana, dapat disimpulkan bahwa nilai ZScore Altman berpengaruh terhadap harga saham sebesar $21,50 \%$ sedangkan $78,50 \%$ dipengaruhi faktor lain.

Dari keempat penelitian tersebut, hasil penelitian menunjukkan risiko perbankan dengan Altman Z Score, dari tahun 2003-2016 bank-bank yang terdaftar di Bursa Efek Indonesia secara umum dalam kategori bangkrut. Namun, penelitian Ganesha dkk (2012) menunjukkan model nilai $\mathrm{Z}$ pada tahun 2003-2006 tidak bisa menunjukkan tingkat keakuratan yang cukup baik bila diukur per tiap tahun. Penelitian Irwansyah (2017) menunjukkan pada periode 2013-2016, hanya satu bank yakni Bank Jtrust Indonesia Tbk (kode bank BCIC) masuk dalam kategori sehat. Selain itu, Bank Mandiri (Persero) Tbk dengan kode bank BMRI, sudah mulai meningkat dari prediksi kategori bangkrut ke prediksi kategori grey area.

Pada proses penelitian ini, terdapat beberapa keterbatasan di antaranya yaitu penelusuran jurnal hanya bersumber dari satu negara (Indonesia) dan hanya pada bank-bank konvensional yang terdaftar di Bursa Efek Indonesia/ BEI, sehingga tidak dapat mencakup semua database jurnal dan konferensi yang ada. Selain itu, pada penelitian ini menggunakan kategori artikel yang berbahasa Indonesia dan jurnal nasional. Sedangkan jurnal internasional, makalah konferensi, tidak termasuk, demikian pula dengan buku dan majalah.

\section{SIMPULAN DAN SARAN}

\section{Simpulan}

Fokus penelitian (research focuses) pada topik yang telah diteliti adalah risiko perbankan berdasarkan Altman Z Score. Dari keempat penelitian yang ditelaah, persamaannya adalah semua penelitian menggunakan pendekatan penelitian kuantitatif. Hal tersebut berarti untuk menilai Altman Z-Score dalam mengamati risiko perbankan, pendekatan kuantitatif adalah pendekatan yang paling tepat.

Dari keempat penelitian tersebut, hasil penelitian menunjukkan risiko perbankan dengan Altman Z Score, dari tahun 2003-2016 bank-bank yang terdaftar di Bursa Efek Indonesia secara umum dalam kategori bangkrut. Namun, penelitian Ganesha dkk (2012) menunjukkan model nilai $\mathrm{Z}$ pada tahun 2003-2006 tidak bisa menunjukkan tingkat keakuratan yang cukup baik bila diukur per tiap tahun. Penelitian Irwansyah (2017) menunjukkan pada periode 2013-2016, hanya satu bank yakni Bank Jtrust Indonesia Tbk (kode bank BCIC) masuk dalam kategori sehat. Selain itu, Bank Mandiri (Persero) Tbk dengan kode bank BMRI, sudah mulai meningkat dari prediksi kategori bangkrut ke prediksi kategori grey area.

\section{Saran}

1. Pada proses penelitian ini, terdapat beberapa keterbatasan di antaranya yaitu penelusuran jurnal hanya bersumber dari satu negara (Indonesia) dan hanya pada 
bank-bank konvensional yang terdaftar di Bursa Efek Indonesia/ BEI, sehingga tidak dapat mencakup semua database jurnal dan konferensi yang ada. Disarankan untuk penelitian lanjutan meningkatkan jumlah hasil riset yang ditelaah dan mencakup semua database baik jurnal maupun konferensi.

2. Pada penelitian ini menggunakan kategori artikel yang berbahasa Indonesia dan jurnal nasional. Untuk penelitian lebih lanjut, disarankan menggunakan jurnal internasional, makalah konferensi, termasuk pula buku dan majalah.

\section{DAFTAR PUSTAKA}

Ganesha, Agha Swara, Tomy G. Soemapradja, Darman, Desmizar (2012). BINUS BUSINESS REVIEW Vol. 3 No. 2 November 2012: 719-736

Altman, E. I. (1968) . Financial Ratios, Discriminant Analysis and the Prediction of Corporate Bankruptcy. Amerika Serikat: Journal of Finance.

Bank Indonesia.(2002). Buku Direktori

Perbankan Indonesia. Jakarta: Bank Indonesia

Dendawijaya, L. (2005). Manajemen Perbankan. Bogor: Ghalia Indonesia.

Fakhrurozi. (2007) Analisis Pengaruh Kebangkrutan Bank dengan Metode Altman Z Score terhadap Harga Saham Perusahaan Perbankan di Bursa Efek Jakarta. Universitas Negeri Semarang, Semarang

Foster, G. 1986. Financial Statement Analysis. 2nd ed. Prentice Hall Int.Inc. USA.

Hadad, M. D., Santoso, W., Sarwedi, H. S. dan Adenan, M. (2004). Model Prediksi Kepailitan Bank Umum di Indonesia. Jakarta: Bank Indonesia.
Hanafi, M. M. dan A. Halim. (2005). Analisis Laporan Keuangan. AMP-YKPN. Yogyakarta.

Hanafi, M. M. (2008). Manajemen Keuangan. Edisi kesatu. BPFE-Yogyakarta. Yogyakarta.

Martono, Nanang. (2015). Metode Penelitian Sosial: Konsep-konsep Kunci. Rajawali Press, Jakarta.

Hartono, J. (2004). Metodologi Penelitian Bisnis: Salah Kaprah dan Pengalamanpengalaman. Yogyakarta: BPFE.

Irwansyah. (2017). Prediksi Kebangkrutan Perusahaan dengan Menggunakan Metode Altman Z Score pada BankBank Konvensional yang Terdaftar di Bursa Efek Indonesia (BEI). LPPM STIE Binaniga, Bogor

Kamal, Siti Ibrah Mustafa . (2012). Analisis Prediksi Kebangkrutan pada Perusahaan

Perbankan Go Public di Bursa Efek Indonesia (dengan Menggunakan Model

Altman Z Score). Jurusan Manajemen Fakultas Ekonomi Bisnis Universitas Hasanuddin.

Kusumastuti, R. (2001). A Study to Formulate a Bankruptcy Prediction Model for the Manufacturing Industry in Indonesia. Yogyakarta: Universitas Gadjah Mada.

Muljono, T. P. (1995). Analisa Laporan Keuangan untuk Perbankan. Jakarta: Djambatan.

www.bi.go.id

Sumber Internet

(http://keuangan.kontan.co.id/news/inilah-4faktor-yang-akan-mempengaruhi-bisnisbank, 2014).

www.idx.go.id 